\title{
Monuments of Wooden Architecture of the Tver Region: Architecture and Traditions
}

\author{
Andrei Bode ${ }^{1,2, *}$ \\ ${ }^{1}$ Scientific Research Institute of Theory and History of Architecture and Town Planning, Branch of the Federal \\ State Budget Institution "Central Scientific-Research and Project Institute of the Construction Ministry of \\ Russia", Moscow, Russia \\ ${ }^{2}$ Federal State Budget Educational Institution of Higher Education, "Moscow State University of Civil \\ Engineering (National Research University)", Moscow, Russia \\ *Corresponding author. Email: bode-niitag@yandex.ru
}

\begin{abstract}
The Tver region, despite significant losses, has preserved many monuments of wooden architecture of the XVIIXIX centuries. The article presents the most significant historical wooden objects of the region. Their architectural and stylistic assessment is given, their historical and cultural value and significance are revealed. The condition of their structures and the degree of loss of their original appearance are characterized and the prospects for preservation are outlined. The objects under consideration are systematized according to the typological principle. Within the main typological groups, objects are analyzed from an architectural and stylistic point of view. The range of objects has been significantly expanded due to the lost objects. As a result, an understanding of the whole picture of the wooden architectural heritage of the region was obtained. Regional architectural features are revealed and their stylistics is revealed. The presented material is relevant for heritage protection bodies, architects and restorers.
\end{abstract}

Keywords: Russian wooden architecture, Wooden churches, Traditions.

\section{INTRODUCTION}

Wooden architecture is a vivid and distinctive manifestation of national culture [1]. The Tver region is not among the northern Russian regions, rich in architectural heritage. However, on closer inspection, you can see that numerous monuments of wooden architecture have survived until the present day, and many of them are unique. The monuments of wooden architecture of the Tver region are described according to the typological principle: churches, chapels, and residential buildings. The sections of this paper present architectural typology, for example, the churches are divided into the tiered type, consisting of different forms, and the klet' (cage) type. Local architectural traditions are revealed.

*Fund: This study is based on the research, supported by the Program of Fundamental Research of the Russian Academy of Architecture and Construction Sciences and of the Ministry of Construction, Housing and Utilities of the Russian Federation 2021.

\section{CHURCHES}

A number of wooden historical buildings are exhibited in the open-air museum "Vasilevo" near the town of Torzhok. Two churches - the 1732 Spasskaya Church (the Church of the Savior) from the village of Spas-na-Sozi and the 1742 Znamenskaya (the Church of the Theotokos of the Sign) from Pylyovo village, as well as two chapels, and a number of peasant residential and household buildings were moved here.

The Spasskaya Church is finely-shaped and it is surrounded on three sides by high galleries resting on consoles; the top part of the main log structure has the so called "poval" (widening), which is quite rare in klet' type churches. The Znamenskaya Church is characterized by a complex arrangement in plan and sturdier proportions. Both churches belong to the same type, but demonstrate a variety of architectural designs. The chapels, the residential and household buildings, being picturesquely scattered on the territory of the museum in groups 
or alone, reproduce the environment of the rural settlement of the Tver region. Admittedly, the museum is not large; hence, its exhibits fail to reflect the architectural diversity of the region.

Two of the most outstanding monuments of wooden architecture in the region remaining in their historical places are the churches in the village of Shirkovo and in Torzhok.

The Church of Saint John the Baptist (1694) in Shirkovo pogost, located on the bank of Lake Vselug, is very expressive and unusual in its architectural design [2]. Its main log structure consists of three quadrangles decreasing with height with eightfold sloping roofs. It is crowned with a massive cupola. The height of the building reaches 40 meters ("Figure 1").

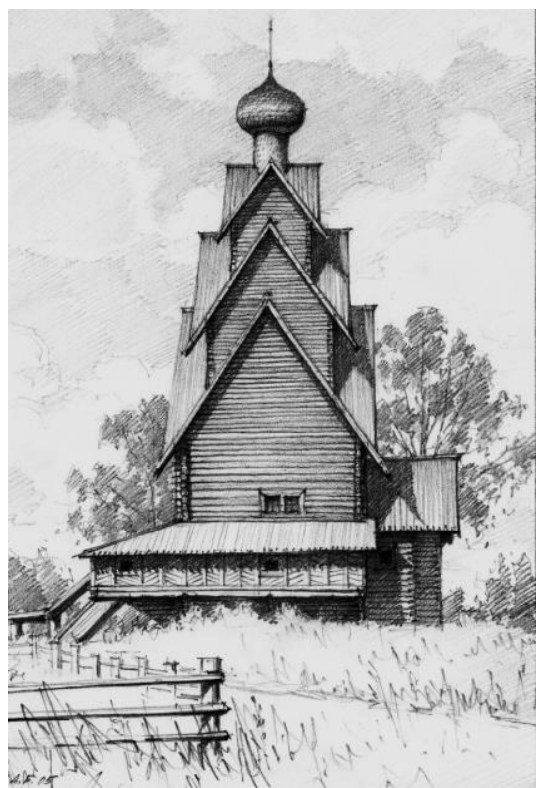

Figure 1 The Church of Saint John the Baptist, Shirkovo village, 1694.

Despite unconventional architectural design, there existed similar churches like the one in Shirkovo, though they were not preserved. Amongst such is a church of the late $16^{\text {th }}$ century in Saint Nilus Stolobensky Monastery, depicted in several icons, and a church in Torzhok, captured by a drawing of a Dutch traveler N. Witsen [3]. Such churches were obviously typical of the Tver land. In Shirkovo, we can see a unique and the only surviving example of a tower-like tiered quadrangle-based church.

During its long history, the Church of Saint John the Baptist could not escape rebuilding. During the 1970 s restoration, the monument was brought to its original appearance - the planking was removed, the hanging gallery was uncovered, and the porch was recreated in place of the removed steeple added in the 19th century. At present, the church again requires restoration, maybe a more complex and a large-scale one, because it is necessary to reinforce the bearing structure of the building.

The Tikhvinskaya Church (the Church of the Theotokos of Tikhvin) in Torzhok (1717) rises on the Tvertsa River bank and is visible from all around the neighborhood. Originally, it was the Voznesenskaya Church (the Church of Ascension), but it was re-consecrated after reconstruction in 1883 [4]. For its main part, the building has a quadrangle and three decreasing with height octagons, crowned with a large cupola. On the east, there is a five-sided altar attached, and in the west a small refectory. Just like the church in Shirkovo, the church in Torzhok has a pillar-like high-rise character ("Figure 2"). The Tikhvin Church has a high interior with the upper tiers open to the inside, and a painted ceiling. The church belongs to a previously common type of tiered churches, however, at present, there are very few of such buildings left. It is one of the most beautiful tiered churches. The monument also needs restoration.

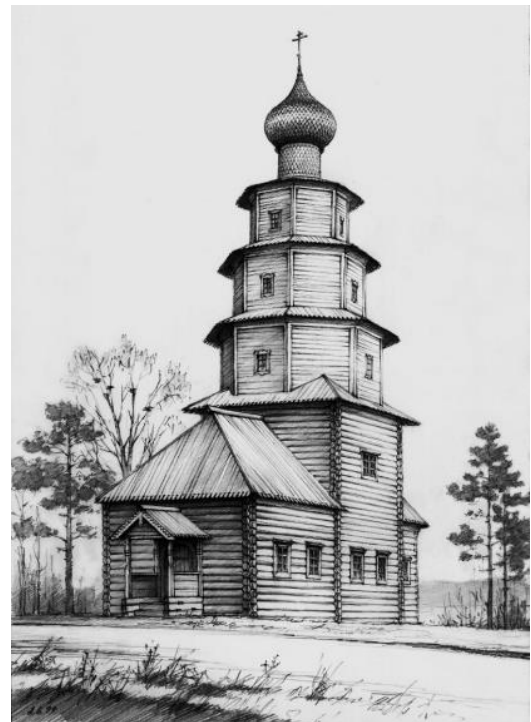

Figure 2 The Tikhvinskaya Church in Torzhok, 1717.

The churches in Shirkovo and in Torzhok are well known and documented, and yet, in the different districts of the Tver region, one can find many more remarkable monuments of wooden architecture of the $18-19^{\text {th }}$ centuries. For example, the well-preserved 1777 Pokrovskaya Church (the Church of the Protection of the Holy Virgin) in the village of Novy Stan, Likhoslavl'sky district. In the 
$19^{\text {th }}$ century, it was renovated; the wall cladding, classical porticos, a new roof and other details were added. However, in its core it is a very rare now type of church. The main structure consists of an octagon based on a quadrangle, and a dome roof; the five-sided altar also has a vault-type roof. These are the primal forms of the church, and, most likely, it has a log structure on the inside. This monument is completely unexplored.

The 1726 Znamenskaya Church (the Church of the Theotokos of the Sign) in the village of Sushigoritsy, Sandovsky district, and the 1773 Uspenskaya Church (the Church of Dormition in the village of Moldino, Udomel'sky district, are relatively well preserved at the building base, but have the top elements missing. The sidewalls clearly show traces of original and now lost galleries or annexes. The same traces indicating the loss of top structures are undoubtedly present in the attics. These churches are now in a dilapidated state, though they still have roofs. If studied and restored, they could become quite interesting objects of the local cultural heritage.

Some churches have partially destroyed roofs and are in a critical condition. Among them is the 1780s Church of the Nativity of the Mother of God in the village of Dryutskovo, Bezhetsky district. In the 1970s, the church dimensions were measured, and the restoration project was developed. This is a high-rise tiered church, resembling the church in Torzhok, only the top tiers are missing. In the $19^{\text {th }}$ century, the window casings and the doorways in the main $\log$ structure and the altar were re-built, the walls were paneled, and a spacious refectory was added on the western side. The roof of the main log structure collapsed.

The Church of Saint Michael the Archangel in the village of Arkhanskoye, Sandovsky district, and the Saint Nicholas Church in the village of Bolshie Setki, Kashinsky district, have similar forms and date back to the $19^{\text {th }}$ century. However, the traces on the walls indicating a different pattern of fenestration and the presence of galleries suggest that these churches can date back to the $18^{\text {th }}$ century. These churches are designed as octagons on the quadrangle with a dome roof, like the churches in the village of Novy Stan.

The three monuments mentioned above are in danger of total destruction. However, they can still be preserved if urgent emergency measures are taken. A similar Pokrovskaya Church (1715) (the Church of the Protection of the Holy Virgin) in Pokrovskoye village, Toropetsky district, has been practically lost. A number of monuments lost very recently, in the beginning of the $21^{\text {st }}$ century, are also worth mentioning. These are the 1709 Kazan Church in the village of Surushino, Kuvshinovsky district ("Figure 3") and the 1726 Church of Saint John the Baptist in the village of Beryozovy Ryadok, Bologovsky district. The church dimensions in Surushino have been recorded, which allows for its reconstruction [5].

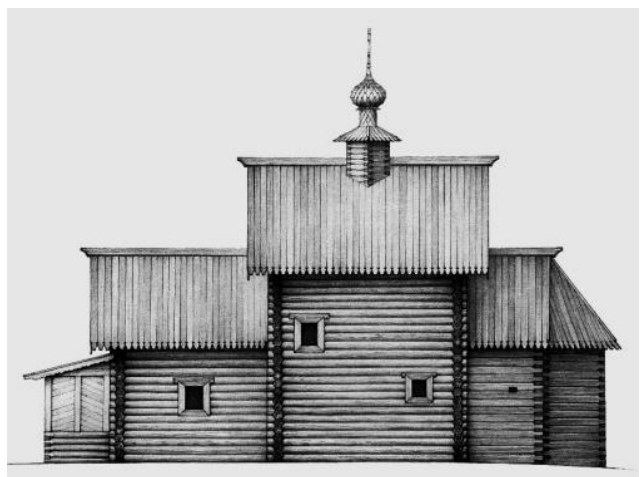

Figure 3 The Kazan Church, Surushino, 1709.

In the Soviet period, architects and restorers neglected wooden churches. The works published in recent years fill this gap [6]. Nowadays, when we have witnessed so many losses of wooden architecture, it is evident that such attitude is wrong. More recent buildings also constitute a valuable cultural layer, even more vulnerable than the older buildings, in which case efforts are made for their preservation. The 1887 Saint Nicholas Church in Rantsevo, Selizharovsky district, is noticeable for its size and complex architectural planning. The 1882 Kazan Church in Seltso Karel'skoye, Udomel'sky district, is smaller and simpler in forms. It should be noted that both churches have very few chances of preservation. The fate of the Saint Nicholas Church in Dymtsevo, Maksatikhinsky district, is dramatic. The refectory and the lower part of the main log structure have already been destroyed, and the upper part with the roof and the cupola have sunk to the ground.

\section{CHAPELS}

In addition to the churches described, many chapels have been preserved in the Tver region. The majority of these chapels date back to the $19^{\text {th }}$ century; however, there are earlier buildings among them, too. For example, the Chapel of the Transfiguration of the Savior dating back to the $18^{\text {th }}$ century, this chapel is one of the few restored, and quite well restored, too, with careful preservation of the original material. 
Unfortunately, the same cannot be said about another restored monument - the Chapel of the Saints Zosima and Savvaty in Gorki, Penovsky district. The building was in a very dilapidated state, with the gallery partially collapsed and the roof leaking. In the 2000s, the chapel was partially disassembled and re-built with the use of new materials, and only several of the original logs were preserved. The main forms remained the same, yet, this building can hardly be called a historical one.

There are a number of relatively well-preserved chapels with intact roofs, but some elements partially lost or destroyed. In the Staritsky district, in the villages of Malinniki and Kushnikovo, two chapels, almost identical in their architecture, are located. They consist of an octagon base, bearing a small top quadrangle tier. This is quite an unusual planning, since most church buildings have the reverse composition - an octagon on a quadrangle. The transition of the octagon into the quadrangle creates surfaces similar to a faceted vault. The octagon in the foundation of the chapels is also unconventional - it is inequilateral. The corners of the quadrangle on the facades of both chapels are decorated with similar-patterned sawn carving. The Chapel of Saint Elijah in the village of Rodnya, Staritsky district, has very expressive architecture, as it consists of the main octagon, covered with a complex roof, above which rises an octagonal tier with a tented roof. The chapel in Konoplino, Molokovsky district, also belongs to the tiered type of buildings, although numerous reconstructions and element losses in the Soviet period do not allow for the evaluation of its original appearance. The Chapel of the Tikhvin Icon of the Mother of God in the village of Trubino, Spirovsky district, has very simple forms, but it is evident that many elements of its original appearance have been lost. The Chapel of Dormition in Telyakovo, Firovsky district, is a classical klet' type building, resembling a small peasant barn.

A considerable number of chapels are in a critical condition or even close to destruction. These objects can still be preserved, if emergency conservation works are undertaken. An octagonal chapel in Zamorino, Firovsky district, still has the log walls, but they are exposed to rain, as it has already lost the roof. The Chapel of Florus and Laurus in the village of Sosnovitsa, Udomel'sky district, is in the same devastating condition. The chapel of the Kazan Icon of the Mother of God in the village of Luginino, Udomel'sky district, consists of an octagon log structure with a helmet dome resting on a high drum. The chapel has a beautiful silhouette, although its condition is alarming. The Chapel of Saint George the VictoryBearer in the village of Lukhnovo, Spirovsky district, with its complex architectural arrangement, looks like a small church, but the roofing of the main log structure and the top of the steeple have already been lost, and it is rapidly dilapidating. The main log structure of Saint Nicholas Chapel in the village of Spasoklinye, Spirovsky district, has wellpreserved walls, but has lost the top tier, and there is a gaping hole in place. The Krestovozdvizhenskaya Chapel (the Chapel of the Exaltation of the Holy Cross) in Vinzha village, Spirovsky district, was re-built in the Soviet period, and thanks to its use for some other functions, it was preserved, though it lost its top elements. The Chapel of Dormition in the village of Medvedikha, Rameshkovsky district, which was in a very critical condition, started to be reconstructed by the local residents. Restoration of the temple is an admirable initiative in itself, but in this case, no professional restoration methods have been applied, the chapel is simply being rebuilt, which does not imply the preservation of its historical appearance.

The listed chapels of the Tver region have a variety of architectural arrangements making them different from the chapels of some other regions. Of special interest are the unusual tiered chapels, the appearance of which echoes with the tiered churches typical for this area.

Performing emergency conservation works on the chapels incurs significantly lower costs than on the churches, but unfortunately, this is not done, either.

\section{RESIDENTIAL BUILDINGS}

In addition to the churches and chapels, in the villages and settlements of the Tver region there are still some traditional peasant buildings of the late $19^{\text {th }}$ - early $20^{\text {th }}$ century left. In some places, one can still see old houses built of thick logs, living out their remaining days; on the outskirts of the villages, among the wooden board sheds, one would catch a glimpse of a wooden barn with an awning ("zalobnik") and a door frame with side jambs, or a large old public barn a short distance away from the main building.

Wooden manor houses are another type of wooden architecture monuments. There are very few of them left. An interesting example of this type is the manor in the village of Yogna, Ves'yegonsky district of the Tver region. It was 
built supposedly in 1908 and belonged to P.P. Gronsky [7].

This wooden house has been preserved to this day in poor condition, but despite this, the original planning structure is easily observed. The house is remarkable for its numerous elements and details in the Art Nouveau style, preserved to this day, which are combined with open log walls. The inner surfaces of the walls were hewed into square corners and, apparently, did not originally have any internal panels or wallpaper. The same applies to the floor and the ceiling. The lack of interior decoration suggests a comparison of this manor house to a traditional Russian log hut ("izba").

The inside of the manor house contains a halfruined glazed tile stove. Under the more recent roof covering, one can see the original one - wooden shingles.

Until recently, the building was in a satisfactory condition and needed minor repairs and restoration. After the gable roof of the two-storey part of the building collapsed, the condition of the building sharply deteriorated. The monument has no owner, and it is not protected by the state, hence, its fate is rueful, though the wooden manor house in the village of Yonga is considered to be a prominent historical and cultural object of the Tver region. This building is famous for the fact that an outstanding Russian artist I.Ya. Bilibin visited it several times and spent a long time there. After restoration, this wooden house could host the Bilibin's museum.

\section{CONCLUSION}

To conclude, the monuments of wooden architecture of the Tver region described in this paper reveal that today there exists a substantial and valuable cultural layer on the brink on disappearance. These losses cause significant damage to the architectural heritage of the region, as well as the whole country.

It is clear that there is no sufficient funding for complete restoration of all these objects, but they would be saved by emergency-prevention and conservation work. Such work does not require costly projects, expert reviews and complex approvals. It would be enough to develop only a small-scale emergency work project and then implement it. The state bodies responsible for the protection of monuments should take care of this and facilitate the implementation of such works, although now we see an almost complete lack of action on their part.

An important direction in the preservation of endangered heritage is the involvement of public initiatives. Today, there are several NGOs involved in the preservation of the monuments of wooden temple architecture in their historical places. Annually, the volunteers of such organizations as "Obshchee delo" ("The Common Cause") and "Verenitsa" carry out dozens of initiatives. These measures really contribute to the preservation of the monuments.

As for the objects that obviously cannot be preserved, their architectural measurements should be taken and recorded. Field studies should be accompanied by the study of historical and archival sources, which contain a large amount of information and are still insufficiently studied [8]. This simple set of works will allow for reconstruction of the lost monuments in the future, given the possibility and will.

The situation with wooden monuments in the region is similar to the situation in the country in general. First of all, the objects need to be systematized by their type, size, condition and, accordingly, the types of work that must be performed in order to preserve them. It is important to highlight once again, that the experience of public initiatives in the preservation of wooden churches deserves our special attention.

\section{AUTHORS' CONTRIBUTIONS}

This paper is independently completed by Andrei Bode.

The author has studied the monuments of wooden architecture of the Tver region. Most of the objects were examined in nature and graphic drawings were made ("Figure 1" and "Figure 2"). The monuments are systematized according to the typological principle. Churches are classified by type of completion. Local architectural traditions are considered and their individuality is revealed. The church in Surushino before the destruction was measured in detail by the author and graphic reconstructions of the original appearance were made ("Figure 3"). The assessment of the possibilities of social movements in the preservation of cultural heritage objects is given. 


\section{REFERENCES}

[1] E. Khodakovsky, Wooden Church Architecture of the Russian North, Regional schools and traditions (14th-19th centuries), Routledge, London, New York, 2016. DOI: https://doi.org/10.4324/9781315723181

[2] A.V. Opolovnikov, Russian Wooden Architecture, Buildings of the Tent-Roof Type, Buildings of the Klet' Type and Small Architectural Forms, Buildings of the Tiered, Kub and Multi-Domed Type (Russkoe dereviannoe zodchestvo. Pamiatniki shatrovogo tipa. Pamiatniki kletskogo tipa i malye arkhitekturnye formy. Pamiatniki iarusnogo, kubovatogo i mnogoglavogo tipa), Art (Iskusstvo), Moscow, 1986, pp. 241-246 [in Russian].

[3] M. I. Milchik, Old Russian iconography of monasteries, temples and cities of the XVIXVIII centuries: Articles 1973-2017 (Drevnerusskaia ikonografiia monasty`rei, hramov i gorodov XVI-XVIII vekov: Stat $i$ 1973-2017), The Publishing House Kolo, Saint-Petersburg, 2017, pp. 291-293 [in Russian].

[4] A.V. Opolovnikov, Treasures of the Russian North (Sokrovishcha Russkogo Severa), Stroiizdat, Moscow, 1989, pp. 244-247, 255 [in Russian].

[5] A. B. Bode, Kazan Church in the village of Surushino, Tver region. Loss of the monument (Kazanskaia tserkov' $\mathrm{v}$ derevne Sushkovo Tverskoi oblasti. Utrata pamiatnika), in: Wooden architecture. New materials and discoveries (Dereviannaia arkhitektura. Materialy i otkrytiia), Vol. II, The Publishing House Kolo, Moscow, Saint-Petersburg, 2011, pp. 244-256 [in Russian].

[6] E. V. Khodakovsky, Wooden church architecture of the Russian North of the XIXearly XX century. The Chronicle of Church building (Dereviannaia tserkovnaia arkhitektura Russkogo Severa XIX-nachala XX v. Letopis' hramostroitel'stva), The Publishing House Kolo, Saint-Petersburg, 2020 [in Russian].

[7] G. K. Smirnov, The collection of monuments of architecture and monumental art of Russia. Tver region (Svod pamiatnikov arhitektury` i monumental`nogo iskusstva Rossii. Tverskaia oblast'), Part 3, Indrik, Moscow, 2013, pp. 6769 [in Russian].

[8] E. V. Khodakovsky, A. G. Noskova, Archival and historical documents in contemporary research of the wooden architecture of the Russian North, in: Evgeny Khodakovsky and Siri Skjold Lexau (ed), Historic Wooden Architecture in Europe and Russia. Evidence, study and restoration, Brikhauser, Basel, 2016, pp. 78-91. 